\title{
Statistical reasoning through metacognitive brain-based learning
}

\author{
W Susilawati', $R$ Abdullah' ${ }^{2}$ dan M N Abdullah3 \\ 1,3 Department of Mathematics Education, UIN Sunan Gunung Djati \\ Bandung, \\ ${ }^{2}$ Department of Da'wah and Communication of UIN Sunan Gunung Djati \\ Bandung, \\ *wati85@uinsgd.ac.id
}

Received: 07 April 2020 ; Accepted: 15 Mei 2020 ; Published: 20 Juni 2020

\begin{abstract}
Abstrak
Rendahnya kemampuan penalaran statistik mahasiswa, menuntut inovasi pembelajaran yang bermakna. Tujuan paper menganalisis kemampuan penalaran statistik mahasiswa melalui pembelajaran brain-based learning dengan strategi metakognitif. Metode Quasi Eksperiment, Nonequivalent Pretest-Posttest Control Group design, melibatkan sampel dua kelas mahasiswa Semester III Universitas Swadaya Gunung Djati Cirebon. Instrumen tes penalaran statistis, dan Tes pengetahuan awal statistik. Hasil penelitian menunjukkan adanya peningkatan kemampuan penalaran statistik antara mahasiswa yang melaksanakan brain-based learning dengan strategi metakognitif berada pada kategori pandai, lebih tinggi dari mahasiswa yang pembelajaran ekspositori berada pada kategori cukup. Berdasarkan pengetahuan awal statistis (pandai, cukup, lemah) mahasiswa yang melaksanakan brain-based learning dengan strategi metakognitif, lebih tinggi dari mahasiswa yang pembelajaran ekspositori. Terdapat interaksi antara jenis pembelajaran serta kategori pengetahuan awal statistis terhadap peningkatan kemampuan penalaran statistis mahasiswa. Pembelajaran brain-based learning dengan strategi metakognitif dapat memfasilitasi proses konflik, penemuan, interaksi sosial, dan proses reflektif mahasiswa sehingga kemampuan penalaran statistis mahasiswa lebih baik dari pada pembelajaran ekspositori.
\end{abstract}

Kata kunci: pembelajaran aktif, metakognitif, penalaran statistik

\begin{abstract}
The low ability of students' statistical reasoning needs a promising learning innovation. The aim of this paper is to evaluate students' learning abilities through brain-based learning with metacognitive strategy. The Quasi Experiment Method, Nonequivalent Pretest-Posttest Control Group design, involved a sample of two classes of third semester students from Gunung Djati Swadaya University Cirebon. Instruments of this paper are statistical reasoning test and statistical preliminary knowledge tests. The result shows an increase in the ability of statistical reasoning among students who conducted brain-based learning with metacognitive strategy in the smart category, higher than students who applied expository learning strategy that only classified as the moderate category. Based on initial statistical knowledge (low, middle, and high) students who applied brain-based learning with metacognitive strategy, got a higher level than students who applied expository learning strategy. It shows interaction between the type of learning as well as initial statistical knowledge with the escalation of the ability of statistical reasoning. Brain-based learning with metacognitive strategy facilitates the process of conflict, discovery, social interaction, and reflective processes of students. Therefore, students abilities of statistical reasoning are better than expository learning strategy.
\end{abstract}

Keywords: Active Learning, metacognitive, statistical reasoning 



\section{INTRODUCTION}

Statistics plays an important role in life. It is widely used by the community, from activities in laboratories, research, psychology, medical personnel, journalists and political observers. Moreover, statistics are used by industrial companies in the world to get the best results. Japan is one of the country that has successfully applied statistics, especially to enhance the marketing opportunity with a variety of products such as cars, motorcycles, and other electronic goods (Rosidah, 2016).

Higher education curriculum is designed with the aim of producing the best quality graduates that matches the qualifications in the National Qualification Framework. Curriculum development strategies facilitate students to develop the knowledge as well as to become an achiever and to master various fields of knowledge. Moreover students are required to be able to apply their ability and knowledge that they need in their daily lives, including statistics. In accordance with Garfield's opinion (Nurhairiyah \& Benefit, 2013) one's ability to form a statistical material will help the students to understand basic concepts, logic of statistical reasoning, practical ability of choosing, producing and interpret descriptive and inferential method in a correct way. Statistical reasoning is a form of reasoning associated with probabilistic numeric.

Statistical reasoning can be utilized in the process of conclusion and decision making in conditions that cannot be expressed from the standpoint of probability that widely known and recognized. In order to develop statistical reasoning, needs another reasoning to deepen about how people learn statistics. It will require a statistician who understand psychology and behavioral science, as a result, it will be obtained in-depth knowledge and make significant changes, Scherkenbach (1991); Snee, (1993); (Martapura 2012). Significant changes will require the involvement of the American Statistical Association (ASA), leaders, individuals, groups, departments, universities, and etc. Statisticians have long recommended that scientists to use statistical reasoning to improve their work. It is time for statisticians to practice and utilize what they know about behavioral science and how people learn to improve the content and the way of delivering statistical education, Snee, (1993); (Martapura 2012).

Statistical reasoning is defined as a way of reasoning using statistical ideas, and it can be understood from statistical information including; the making of interpretation based on data, data representation, or summary of data collection, a form of statistical reasoning can be a combination of ideas about data and opportunities, such as inference and interpretation of statistical results (Nisa, Zulkardi, Susanti (2019). According to Yusuf (2017) statistical reasoning specifically predict phenomena that occur based on data collection results from measurements to interpret, understand, and make good decisions, so that statistical reasoning consists of structural, unistructural, multistructural, and relational.

Chan and Ismail (2014) state that there are four concepts in the assessment of statistical reasoning such as: describing data including perusing raw data or data presented in tables, diagrams or graphs, organizing and reducing data including compiling, classifying or combining data into concise form , representing data includes presenting data into graphical form and involves basic rules relating to representation, analyzing and interpreting data including recognizing trends and shapes as well as making conclusions or predictions from data.

The ability of statistical reasoning is very important to be owned and developed. Empirically, the facts show that the statistical reasoning ability of students is still low. This is seen from the results of a preliminary study conducted over several semesters of students, showing that the students' statistical reasoning ability is still in the low category. This can be seen from 37 students, 30 students still have 
difficulty in solving reasoning questions that must be accompanied by reasons and questions that are not simple (involving various concepts). Only 7 students can solve these problems. In other words, only $25 \%$ of students are able to solve statistical reasoning problems. Maryati's (2017) research results shows that one of the difficulties of students in solving statistical problems is to conclude.

One of alternative that is thought to be able to overcome these problems is to apply brainbased learning with metacognitive strategies. There are several advantages of integrating a brain based learning approach with metacognitive strategies such as, the learning process is setted to facilitate interaction between students to actively thinking of the constructing, planning problem solving that arises through interaction with the environment, so that metacognitive as a stimulus in thinking is able to link, plan, understand, control, and assess the process authentically, according to contextual issues (Susilawati 2017). The BBL syntax model with metacognitive strategies are: (1) pre-exposure, (2) preparation, (3) initiation and acquisition, (4) elaboration, (5) incubation and inserting memory, (6) verification and checking of beliefs, and ( 7) celebration and integration, Uzuntiryaki-kondakci, Capa-Aydin (2013). Ulfah (2013) states that statistical reasoning with contextual learning is better than conventional learning.

In the Brain Based Learning setting, sitting position of the students correlates with the value that obtained, according to the result of Kausar, F (2019); Chandran, R. (2015); Boeren, E. (2017). Cuseo, J.B., Thompson, A., Campagna, M., \& Fecas, V.S. (2016); D'souza, G. A. (2018); (Ibáñez, V., Pérez, S., Silva, J., \& Tamarit, S. (2019) that the choice of seating positions in the classroom can reflect student motivation, which influences learning outcomes, the habit of seat selection in the front row tends to avoiding the noise of their classmates in following the lessons. Comfortable learning settings will help to facilitate the work of the brain to optimally connecting the knowledge possessed with the material that being studied (Jensen, 2008).

Learning with metacognitive strategies is learning that instills an awareness of how to design, monitor and control about what they know, what is needed to do and how to do it (Maulana, 2008). The metacognitive strategy is carried out in three stages, namely the conscious learning process stage, the learning planning stage, the monitoring and the learning reflection stage (Romli, 2009). Metacognitive can be assessed using a questionnaire to report students' perceptions and problem-solving abilities, Downing, (2009); (Namira, Kusumo, Prasetya, 2014).

Explicitly the aim of the study was to analyze: increasing the ability of statistical reasoning between students who took brain-based learning with metacognitive strategies and expository learning based on overall students and the Preliminary Knowledge Statistics (PAS) of students at the level of smart, moderate and weak. Analyzing the interaction between types (brain-based learning with metacognitive and expository strategies) and Based on initial statistical knowledge (low, middle, and high) categories to increase students' statistical reasoning abilities.

\section{METHOD}

Quasi-experimental method. nonequivalent pretest-posttest control group design. Involving a sample of third semester students of Gunung Djati Swadaya University Cirebon who took educational statistics courses, class A was an experimental group carrying out brain-based learning with metacognitive strategies and class $\mathrm{B}$ as a control group carrying out expository learning. The instrument of statistical reasoning ability tests. Data analysis: Independent t-test, Adjusted Rank Transform Test, two-way ANOVA.

\section{RESULT AND DISCUSSION}


To see the difference in increasing statistical reasoning ability between groups of students who carry out brain-based learning with metacognitive strategies and who get expository learning, data processing is performed, the results of statistical reasoning ability tests from the pretest and posttest scores obtained the value of $n$-gain test for statistical reasoning ability. The average n-gain test for statistical reasoning ability of students who carry out brain-based learning with metacognitive strategies gets 0.55 in the smart category, better than students who carry out expository learning with a value of 0.19 in the moderate category.

After going through a series testing data tests the ability of statistical reasoning is normally distributed and has a homogeneous variance. Then the Independent t-test is performed. Independent t-test results for statistical reasoning ability tests are presented in Table 1.

Tabel 1. Independent t-test

\begin{tabular}{cccc}
\hline \multicolumn{4}{c}{ t-test For Equality of Means } \\
\hline $\mathrm{T}$ & $\mathrm{dF}$ & $\begin{array}{c}\text { Sig. (2- } \\
\text { tailed) }\end{array}$ & $\begin{array}{c}\text { Mean } \\
\text { Difference }\end{array}$ \\
\hline-5.687 & 75 & .000 & -.42037 \\
\hline
\end{tabular}

The results of the t-test with the help of SPSS, can be seen in Table 1 with the Sig. (2-tailed) that shows $0,000<0.05$, in that term, H_O is rejected. It means that there is a difference in the increasing of statistical reasoning ability between students who carry out brain-based learning with metacognitive strategies and who get expository learning.

Testing the differences of the improvement of statistical reasoning abilities based on the Based on initial statistical knowledge (low, middle, and high). The assumption of normality and homogeneity of variance is need to fulfill. The results of normality tests on these abilities show that there is an abnormality at the PAS level, Whereas the variance is homogeneous. Due to the normality assumption on the data gain of statistical reasoning ability is not fulfilled, two-way
ANOVA test cannot be performed. As an alternative, nonparametric rules can be used with the Adjusted Rank Transform Test or it can also use the Puri and Sen Aligned Ranks Technique (L Test) enhanced by Harwell \& Serlin to become Aligned Ranks Technic (L Test) in Trace Criterion Form, (Susilawati 2017).

Hypothesis testing using the Adjusted Rank transform Test if the Sig. greater than $\alpha$, for $\alpha$ 0.05, then Ho is accepted, vice versa if the Sig. smaller than 0.05, then Ho is rejected. The results of the recapitulation of data testing the interaction between learning and Based on initial statistical knowledge (BISK) on the ability of statistical reasoning can be seen in Table 2.

Tabel 2. Adjusted Rank Transform Test

\begin{tabular}{|c|c|c|c|c|c|}
\hline \multicolumn{6}{|c|}{ The Ability of Statistical Reasoning } \\
\hline $\begin{array}{c}\text { Sour } \\
\text { ce }\end{array}$ & df & $\begin{array}{c}\text { Mean } \\
\text { Squaar } \\
\text { e }\end{array}$ & F & Sig & Desici \\
on
\end{tabular}

Based on Table 2 for the type of metacognitive BBL learning gives a significant effect on the ability of statistical reasoning with the Sig. $(0,000)$ smaller than 0.05. The same thing also happens at the PAS level which significantly influences the ability of statistical reasoning as indicated by the Sig. $(0,000)$ which is less than 0.05. For the interaction test, based on the type of learning and the level of PAS on the ability of statistical reasoning that the value of Sig. $(0,000)$ is smaller than 0.05 , so it is concluded to reject Ho. It means that there is a significant difference in the achievement of statistical reasoning ability between brain-based learning students with metacognitive strategies and those in expository learning reviewed by PAS. According to the results of Burger, William F. \& 
Shaughnessy, J. Michael. (1986); (Susilawati 2019) research that the initial knowledge of statistics influences the characteristics of the development of statistical thinking skills possessed by students before the process of learning. According to the result of Putra (2015) research, the students' initial statistical knowledge has a low impact on statistical reasoning ability. Furthermore Hevriansyah and Megawanti (2016) research shows that there is a significant influence between students' initial knowledge of statistics on learning outcomes.

Based on table 2 for the effect of the interaction of learning and Based on initial statistical knowledge (low, middle, and high) types on the ability of statistical reasoning, the Sig. o,ooo $<0.05$, then Ho is rejected, it means that there is an interaction effect of the relationship between the types of metacognitive BBL learning with the level of Based on initial statistical knowledge (low, middle, and high), which affects the ability of student statistical reasoning. According to Maron, (2016); Susilawati, (2019) research results, the learning that is carried out in a social constructivist manner, creates, and develops knowledge through assignments, is not the result of receiving information only from the teacher, even in modern conditions, it is professionally cannot rely solely on self-acquired knowledge, the involvement of other teachers and students reconstruct the concept of learning materials to overcome conflicts as well as the practice of completing ongoing tasks is very much needed.

\section{CONCLUSION}

The Increasing of statistical reasoning ability between students who applied brain-based learning with metacognitive strategies in the smart category is higher than students who applied the expository learning that only classified as the moderate category. Based on the initial statistical knowledge (low, middle, and high) students who carry out brain-based learning with metacognitive strategies, higher than students whose learning expository. There is an interaction between the types of learning as well as the category of initial statistical knowledge with improvement of students' statistical reasoning abilities. Brain-based learning with metacognitive strategies can facilitate the process of conflict, discovery, social interaction, and reflective processes of students so that students' statistical reasoning abilities are better than expository learning.

\section{ACKNOWLEDGMENTS}

The authors acknowledge special to DIPABOPTAN 2019 UIN Sunan Gunung Djati Bandung the financial support.

\section{Reference}

Boeren, E. (2017). The methodological underdog, A review of quantitative research in the key adult Education Journals, Adult Education Quarterly, 68 (1), 63-79.

Chandran, $R$ (2015) Mandatory class participation: Factors that influence, classroom practices and learning outcomes. Asian Journal of the Scholarship of Teaching and Learning, 5(2), 108-122.

Chan, S.W, \& Zaleh, I. (2014). Developing statistical reasoning assessment instrument for high school students in descriptive statistics. Procedia-Social and Behavioral Sciences, 116, 43384343.

Cuseo, J, B., Thompson, A., Campagna, M., \& Fecas, $V, S$. (2016). Thriving in college and beyond: research-based strategies for academic success and personal development, Dubuque, IA: Kendall Hunt Publishing. 
Downing, K.J., (2009). Self eficiacy and metacognitive development, The International Journal of Learning. Vol 4, No 16, hal 21-32.

Hevriansyah, P,. Megawanti (2016). Pengaruh kemampuan awal terhadap hasil belajar matematika J. Kaji. Pendidik. Mat. 21 37-44.

Ibáñez, V., Pérez, S., Silva, J., \& Tamarit, S. (2019). Statistical analysis of students' behavioral and attendance habits in engineering education. Educational Sciences: Theory And Practice, 19(4),48-64.

Kausar, F. (2019). A study of relationship between physical facilities in classroomand student's performance: A secondary level study. In M. Ahmad (Eds, Proceedings of 17th International Conference on Statistical Science) Vol. 33, pp. 223-228.

Maron, A, I (2016). Priorities of teaching mathematics in universities" IEJMEInternational Electronic Journal of Mathematics Education, 11 (9), $p p$. 3339-3350.

Maryati. (2017). Peningkatan kemampuan penalaran statistis siswa Sekolah Menengah Pertama melalui pembelajaran kontekstual. Jurnal Mosharafa, 6(1), 129-14.

Maulana, (2008). Pendekatan metakognitif sebagai alternatif pembelajaran untuk meningkatkan kemampuan berpikir kritis mahasiswa PGSD, Jurnal Pendidikan Serambi Ilmu, Vol 2, No 1O, Hal 25-36.

Namira, Z, B., Kusumo, E., Prasetya, A, T. (2014). Keefektifan strategi metakognitif berbantu advance organizer untuk meningkatkan hasil belajar kimia siswa, Jurnal Inovasi
Pendidikan Kimia, Volume 8, No. 1, hal $1271-1280$.

Nisa, S., Zulkardi, \& Susanti, E. (2019). Kemampuan penalaran statistis siswa pada materi penyajian data histogram melalui pembelajaran PMRI. Jurnal Pendidikan Matematika, 13(1), 21-4O.

Putra, R, W. (2015). Pembelajaran konflik kognitif untuk meningkatkan kemampuan komunikasi matematis siswa berdasarkan kategori pengetahuan awal matematis. Al-Jabar Jurnal pendidikan matematika.

Romli, M. (2009). Strategi membangun metakognisi siswa SMA dalam pemecahan masalah Matematika, Skripsi, Madura: FKIP Universitas Madura.

Rosidah. (2016). Penalaran statistis siswa sma dalam pemecahan masalah statistika di tinjau dari perbedaan gender. Prosiding Seminar Nasional. 2(1), 5765.

Siti Nurhairiyah, S., Manfaat, B. (2013). Pengembangan Instrumen Tes Untuk Mengukur Kemampuan Penalaran Statistik Mahasiswa, Journal Eduma,2(2).

Snee, (1999). Discussion: Development and Use of Statistical Thinking: A New Era, International Statistical Review, 67, 255-258.

Susilawati, $\quad W \quad$ (2019).Peningkatan kemampuan berpikir statistis mahasiswa melalui challenge-based learning dengan strategi konflik kognitif. Jurnal analisa, Vol 5, No. 1, h 31- 40 .

Susilawati, W. (2017). Pengaruh pembelajaran berbasis tantangan terhadap kemampuan visualisasi 
spasial, berpikir lateral dan kegigihan matematis mahasiswa, Disertasi SPS UPI.

Ulpah, M. (2013). Peningkatan kemampuan penalaran statistis dan self-efficacy siswa madrasah aliyah melalui pembelajaran kontekstual. Repository UPI Central Library.193-197.

Yusuf, Y. (2017).Konstruksi penalaran statistis pada statistika penelitian. Scholaria, Vol. 7 No 1, 6o-69. 